\title{
ERRATUM
}

\section{Preparation and validation of the first WHO international genetic reference panel for Fragile $\mathrm{X}$ syndrome}

\author{
Malcolm Hawkins, Jennifer Boyle, Kathleen E Wright, Rob Elles, Simon C Ramsden, Anna O'Grady, \\ Michael Sweeney, David E Barton, Trent Burgess, Melanie Moore, Chris Burns, Glyn Stacey, Elaine Gray, \\ Paul Metcalfe and J Ross Hawkins
}

European Journal of Human Genetics (2013) 21, 478; doi:10.1038/ejhg.2012.189

Correction to: European Journal of Human Genetics (2011) 19, 10-17; 10.1038/ejhg.2010.135; published online 25 August 2010

Since the publication of this article, the authors have noticed that the DNA sequence of both the PCR primers in the section
'Methylation analysis' in Materials and Methods is incorrect. They should read:

$5^{\prime}$-TTGAGTGTATTTTTGTAGAAATGG- ${ }^{\prime}$ and reverse $5^{\prime}$-CCCTCT CTCTTCAAATAACCT- $3^{\prime}$.

The publishers would like to apologise for their error. 